\title{
Corporate Sustainability Practices in Polluting Industries: Evidence from India, China and USA
}

\section{Korporacyjne praktyki zrównoważonego rozwoju w branżach zanieczyszczających środowisko: dowody z Indii, Chin i USA}

\author{
Prem Sagar Mishra*, Ajay Kumar*, Niladri Das*** \\ Department of Management Studies, Indian Institute of Technology (ISM) Dhanbad, \\ Jharkhand-826004, India. \\ E-mails:*psmcoal@gmail.com,**ajay.dms16@gmail.com, \\ ***niladri_pnu2003@yahoo.co.in
}

\begin{abstract}
In recent years, the tilt of the corporate world towards non-financial reporting can be clearly seen from traditional accounting practices. Sustainability reporting disclosures are an important tool for providing information about the environmental and social performance of companies to their various stakeholders. From a financial perspective, for any firm, there is always a possibility of reporting more of the information that favours their interests or conceal that which is not in their favour. This study evaluates the annual and sustainability reports of 380 Indian, 400 Chinese and 400 USA companies from five highly polluting industries on the basis of GRI (global reporting initiatives) guidelines. From the result, it is inferred that the findings are consistent with the legitimacy theory. The result shows that the profitability and capital structure of firms in the sample do not affect the sustainability reporting practices significantly. In addition, larger firms have a tendency to disclose more information in their annual and sustainability reports than smaller firms.
\end{abstract}

Key words: environmental management, sustainability reporting, polluting industries, sustainability accounting, legitimacy theory

\section{Streszczenie}

W ostatnich latach wyraźnie widać $\mathrm{w}$ tradycyjnych praktykach rachunkowych przechylenie świata korporacyjnego w kierunku sprawozdawczości niefinansowej. Raportowania zrównoważonego rozwoju są ważnym narzędziem dostarczającym informacji o środowiskowych i społecznych wynikach działalności przedsiębiorstw różnym interesariuszom. Z perspektywy finansowej, dla każdej firmy, zawsze istnieje możliwość zgłoszenia większej ilości informacji, które faworyzują ich interesy lub ukrywają te, które są niekorzystne. W artykule oceniono roczne raporty dotyczące zrównoważonego rozwoju 380 indyjskich, 400 chińskich i 400 amerykańskich firm z pięciu wysoce zanieczyszczających środowisko branż na podstawie wytycznych GRI (Globalnych Inicjatyw Sprawozdawczych). Dokonane ustalenia są zgodne z teorią legalności. Otrzymane wyniki pokazują, że rentowność i struktura kapitałowa firm nie wpływają znacząco na praktyki raportowania zrównoważonego rozwoju. Ponadto większe firmy mają tendencję do ujawniania większej ilości informacji w swoich rocznych raportach i raportach dotyczących zrównoważonego rozwoju niż mniejsze firmy.

Słowa kluczowe: zarządzanie środowiskiem, raportowanie zrównoważonego rozwoju, branże zanieczyszczające środowisko, rachunkowość zrównoważonego rozwoju, teoria legalności 


\section{Introduction}

Today, the corporate landscape is volatile and uncertain. Recent trade wars between China-USA and India-USA have economically as well as politically interrupted the entire global business. In addition to these trade wars, blockchain technology, deep machine learning, cyberattacks, artificial intelligence, protectionism are just a few contemporary risks experienced by new-era corporate managers. Thus, together with worldwide environment change that is becoming more severe than ever, creates fresh challenges for these new-era managers to have a sustainable business in this volatile and uncertain corporate world landscape. Simultaneously, issues related to the sustainability of the environment and economic developments are a matter of concern to all. The conception of sustainability sprouts up from environmental science and portrays the utilization of a selfgenerated earthy system in a manner that it holds its basic properties and helps in replenishing it naturally. In other words, it is the need for enhancing all man-made processes and systems in a more ecofriendly manner. The concept of sustainability is based on the principle of sustainable development, which was first introduced in the report of Brundtland Commission in 1987 (Zhou et al., 2017). Since then, it found its root in various disciplines like management, economics, and social science. Until now, several initiatives have been taken at each and every level of governance to address distinctive aspects of sustainability issues (Mebratu, 1998).

Since the late 1990s, due to an increase in demand for natural resources whose supplies are continuously dwindling, corporations have been forced to look towards the TBL (triple bottom line) approach of sustainability, i.e., profit, people, and the planet (Elkington, 2002). At the same time, the increased unethical practices of various corporations and the formation of new markets raised the concern of various stakeholders for greater attention towards sustainable development (SD) (Tang and Zhou, 2012). As consequence, it has become vital to develop a measurement scale for sustainability that is globally recognized (Tyteca, 1998). Until now, sustainability assessment has fulfilled various noteworthy objectives, which may be classified into four major groups, i.e., strategic management and decisionmaking process, advocacy, building general consensus among all stakeholders and their active participation, and R\&D (research and development) (Parris $\&$ Kates, 2003). These have been applied at the national (Coli et al., 2011), regional (Munda \& Saisana, 2011), industrial (Peres-Neto et al., 2006), individual, corporate, and firm levels (Kuosmanen \& Kuosmanen, 2009). In the earlier phase, the sustainability concept and its assessment module had a primary focus on economic and environmental issues only, but in the later phase of development, it has started to note the social dimension of sustainability as well (Winfield et al., 2010).

The growth and expansion of societies and their livelihood activities have surpassed the ecological limits of the planet (Rockstrom et al., 2009; IPCC, 2014). Instead of adopting the methods and ways for sustainable development, it is only debated in high profile business conferences and global summits. However, a debate exists concerning the role that can be played by the global business units into the aspired transition on the way to a less unsustainable future (Jackson, 2009; Bansal \& Hoffman, 2012; Bebbington \& Larrinaga, 2014; Bebbington et al., 2014). Perhaps the most noticeable element in the management boardroom of corporate offices is to discuss the issues related to sustainable development through sustainability reporting practices that have become an institutionalized stream of information produced by businesses. Despite the increased debate on sustainability issues, a constant decline can be seen in the situation of the natural environment (Milne \& Gray, 2013). A significant gap persists between sustainability reporting and its practices (Spar \& LaMure, 2003).

A firm's economic perspective is to ensure the reduction of cost and enhancement of profit. This is the reason that firms concentrate on disclosure of such key indicators that help in reducing costs significantly. This study aims to identify the relationships among the exhaustive categories of the indicators used in sustainability reporting practices of Indian, Chinese, and USA polluting firms and examine their effect on the financial performance.

This research article is organized as follows: section 1 provides an introduction to the study, followed by background and a literature review in section 2 . Section 3 addresses the data collection and research methodology. Section 4 provides a detailed account of the results. Section 5 is devoted to a discussion and conclusion of the study.

\section{Background and Literature Review}

The various literature sources available on sustainability reporting practices have developed two contrary approaches to address sustainability reports (SRs). One approach addresses the traditional practices perspective in which a firm's principal aim is to maximize the shareholder's value by adopting cost reduction techniques and increasing revenue while adhering to all legal bindings (Husted \& Salzar, 2006; Friedman, 2007). This approach is the most disparaged approach by SR and its practices (Aupperle et al., 1985; McWilliams \& Siegal, 2001; Friedman, 2007; Gamerschlag et al., 2011). The other approach addresses stakeholder perspectives and advocates the supremacy of all stakeholders and a firm that tries to fulfil their demands in the long run, which will provide greater economic profits 
(Frooman, 1999). Different scholars define the sustainability reporting practices paradigm emphasizing different aspects such as socio-ecological concern, corporate ecology, and the institutional theory perspective (Campbell, 2007).Thus, sustainability reporting refers to the TBL (triple bottom line) approach for the long-term survival of the firms (Dyllick \& Hockerts, 2002). Since the 1980s, continuous growth and development has been occurring in the concept of sustainability reporting practices (Kolk 2005; Kumar \& Das, 2018). In the early 1990s, the first voluntary sustainability reports concentrating on ecological aspects was published. Large polluter firms with ecologically sensitive operations received continuous pressure from NGOs (non-governmental organizations) and started to publish sustainability reports. During this period, various models, such as the EMAS (Eco-Management and Audit Scheme), ISO 14000 series, ISO 26000 series, AA1000 standards and GRI guidelines, were developed to address the issue of sustainability. Recently, awareness towards the sustainable development among the various stakeholders is being reflected in the increasing number of SRs in preparation and submission and in the adherence to their provisions (Kolk, 2005).

\subsection{The role of sustainability disclosure in society} Sustainability reporting prompted a significant assortment of research investigating the qualities of this contemporary phenomenon (Parker, 2005; Owen, 2008). There are several studies that explore why private firms are involved in preparing and publishing the sustainability reports (Deegan \& Blomquist, 2006; Clarkson et al., 2008) and its role in society (Gray, 2010; Malsch, 2013). In a broader context, stakeholder's increasing concerns about the impact of operational activities of the various firms on the socio-economic and biosphere drives the firm's reporting ability to produce sustainability reports (Adams \& Narayanan, 2007; Bebbington et al., 2008). Most of the SRs and related research are grounded on the theory of legitimacy (Gray et al., 1995), which is based on the assumption that there is the existence of an implicit contract between the industry and people, where they operate their business activities (Chen \& Roberts, 2010). The spirit of this implicit contract is having the authority of granting and revoking the operations of business activities by the civil society. The civil society permits operation of the business activities by firms within the society, and firms agree to fulfil the societal expectations. These societal expectations are framed with various welfare norms within the society, and the firm's survival depends on its ability to meet them. Generally, the research based on this principle considers a sustainability report as a tool that influences the societal perception towards companies (Lindblom, 1993; Suchman, 1995).

\subsection{Need for measuring sustainability practices in} Indian, Chinese, and American firms

A developed economy like the USA where resources are abundantly accessible and correctly managed, unlike this, India and China are the emerging economies and will have to balance their growth process and consumption pattern of natural resources for equitable distribution among the various stakeholders. Thus, there is a need to frame government policy in such a manner that not only manages the organizational capabilities but also remains socio-ecologically responsive (Sodhi, 2015; Mani et al., 2016). In all economies, government monitors all firms' activities on various issues of sustainable development through various acts and laws and regulates accordingly (Kaur \& Sharma, 2017).

Legitimacy theory is often used to describe the corporate disclosure practices in these scenarios, including the mandatory guidelines since corporate offices see that the regulations are inadequately upheld with rare fines and penalties (Sandhu et al., 2012). At present, many firms either frame their own policies in line with government regulations or follow various globally accepted sustainability reporting practices i.e. GRI guidelines (GRI, 2009).

Either way, biased, incomplete or selective disclosures can always be problematic in a true assessment, and it will be a blunder for various stakeholders to evaluate this report with misleading information in disclosures practices (Spence, 2009). Therefore, there must be uniformity in all types of disclosure practices so that the risk of voluntary considering selective or fragmented information can be minimized. One such de facto standard is the GRI practices that are followed worldwide (GRI, 2009). Comprehensively, it advocates that uniformity in SRs is not only involved in serving the promotion of corporate interests but also acts collectively to display the present structural arrangement of the society, which will lead to acting on the escalating challenges of sustainable development by enhancing the ability of society (Malsch, 2013). Similarly, some scholars argue that by the process of apparent identity transformation, firms are capable of resisting the substantive change towards business-as-usual (Tregidga et al., 2014; Laine, 2010; Milne et al., 2009). Accounting professionals play a significant role in preparing and assuring the international standards of SRs (Malsch, 2013). SRs have an informational mount that pressurizes the management professional to manage firm risk levels by meeting the expectation of the market towards socio-economic and environmental needs. These firm risk levels can only be mitigated by managing the stakeholders. It cannot be managed by considering short-term unilateral profit motive, which leads to negative socio-environmental consequences (Rodrigue et al., 2013). 
A number of scholars claim that worldwide businesses are aware of the GRI reporting module (Kothari, 2013; Kaur \& Sharma, 2017). Some of them are trying to adopt these standards as norms. In this current decade, there is a tremendous increase in the trend of submitting the sustainability reports (GRI, 2013). The firms are performing well on the various indicators of GRI (Godha and Jain 2015; Kumar and Das 2018), but more needs to be done in terms of sustainability (GRI, 2013). Therefore, it is the need of the hour to focus on these largest economies like India, China, and USA which is also home to about 40 percent of total world population. Hence, this study focuses on evaluating the sustainability reporting practices being followed by Indian, Chinese, and USA businesses.

\subsection{Hypotheses Development}

Different relationships among different dimensions have been identified in the existing literature of sustainability reporting and its practices. For instance, the firms that place emphasis on sustainability reporting practices are able to beat their rivals over a long period of time in terms of both accounting performance and market capital (Eccles et al., 2012). Moreover, firms have a more focused approach towards sustainability reporting practices that depend on brand value and reputation and are engaged in producing products that require a huge amount of natural resources (Akisik \& Gal, 2014). Finally, firms with high profitability face higher social and environmental constraints and media exposure than marginally profitable firms. Potential political costs also affect them more (Watts \& Zimmermann, 1990; Fields et al., 2001). A large firm making a huge profit from its operations finds difficult to breach the expectation of the society. SRs are an easy tool for them to explain what and how they produce their profitability than a less profitable company. (Bewley \& Li, 2000; Islam \& Degan, 2010). Additionally, various research studies also suggest that a review of sustainability reporting practices plays a vital role in a stakeholder's decision-making process.

The above exhaustive review of literature has demonstrated that many efforts have been made to examine the linkage between the determinants of sustainability reporting disclosures and corporate performance. Consequently, as per the motivation behind this study, following hypotheses were developed to assess the linkage between corporate financial and non-financial disclosures. Hence, the study proposes the following hypothesis:

H1: Firms' profitability (i.e. Return on Assets (RoA)) of Indian, Chinese, and USA Polluting Industries positively and significantly affects the total sustainability score (TSS).

H2: Firms' size (i.e. the log of total market capitalization) of Indian, Chinese, and USA Polluting Industries positively and significantly affects the total sustainability score (TSS).
H3: Firms' capital structure (i.e. gearing ratio) of Indian, Chinese, and USA Polluting Industries positively and significantly affects the total sustainability score (TSS).

\section{Data Collection and Research Methodology}

In recent years, many firms have shown interest towards adopting the international standards of sustainability reporting, and this interest can be visible in the number of sustainability reports submitted to GRI, which is increasing day by day. Our study focuses on polluting industries from mining and extraction, chemical, pharmaceutical, fertilizer and agrochemical, and cement sectors that are porn to environmental degradation to maintain data homogeneity.

To understand the ability to adopt the international sustainability standards of polluting industries in the Indian, Chinease, and USA context, an exploratory research design followed by statistical analysis was constructed. The final sample in the study consists of 380 Indian listed firms in the NSE (National Stock Exchange), 400 Chinese listed firms in SSE(Shanghai Stock Exchange), and 400 USA firms listed in NYSE (New York Stock Exchange) from various polluters, for which data was available for the time period of 2007-08 to 2016-2017. The reason for consideration of this time frame is that from 2007-08 onwards there has been a considerable movement towards the preparation of sustainability reports by the corporations. All firms in the sample were selected by applying certain filters, i.e., they must be listed in their respective stock exchange before the financial year 2007-08. A detailed list of industry and number of sample firms is mentioned in Appendix 1. Financial data has been collected from the annual reports of the respective firms. Information related to various disclosures of GRI was hand collected using the content analysis of sustainability and annual reports for each year in the analysis period. GRI issued different versions of guidelines from time to time. To have uniformity in the data sets, this study focuses on the latest implemented version of GRI G-4 guidelines.

The study used the content analysis of annual and sustainability reports to find total sustainability score (TSS) as a dependent variable. By using content analysis, the present study evaluates the sustainability and annual reports of different firms based on GRI G-4 guidelines. As the study concentrates on GRI G-4 guidelines, a three-point scoring (0-2) scale is used (Kumar \& Das, 2018). The 91 key indicators of the GRI G-4 guidelines have been considered in this study. The total maximum possible score for a firm for a given year is $182(91 * 2)$. Manual coding was performed to obtaining the score for each subcategory as per GRI G-4 guidelines. If all aspects of the key performance indicator are reported as per GRI guidelines, then it is awarded a score of 2 ; if 
some aspects were found missing or partially reported, then it is awarded a score of 1; and if any indicator has not reported, then a 0 score has been allotted for that particular indicator. The firms in the sample were analyzed for each year, and the sustainability disclosure score was calculated by using following model (Gavana et al., 2016):

\section{$\mathrm{I}=\sum \mathrm{d}_{\mathrm{i}} / \mathrm{M}$}

where $d_{i}$ is the total score obtained by a firm upon the disclosure of indicators and $\mathrm{M}$ is the maximum possible score a firm can obtain.

The study includes variable sets that have been found in previous literature. In this study, return on assets (RoA) is taken as a proxy for profitability and treated as independent variable, while the size of the firm and gearing ratio are used as control variables. The submitted sustainability report (SR) defines the dummy variable that assigns the value of 1 if the SR is published by the firm for the particular year or else 0 .

\subsection{Empirical Model (Panel Analysis).}

The panel data set consists of observations on multiple individuals with each individual being observed at two or more points of time. The sample dataset also has two dimensions, i.e., cross-section and timeseries. Thus, panel data have been collected in this study. The general form of the model used for the analysis of total sustainability is as follows:

Model: Total Disclosure score $=\mathrm{f}($ RoA, control variables).

General mathematical expression of the model is:

$\mathrm{Y}_{\mathrm{it}}=\beta_{i} \mathrm{X}_{i t}+\alpha_{\mathrm{i}}+\mu_{\mathrm{it}}$

where $Y_{i t}$ is the dependent variable at time $t$

$\mathrm{X}_{\mathrm{it}}$ is the independent and control variable at time $\mathrm{t}$ $\beta_{\mathrm{i}}$ is the coefficient

$\alpha_{i}$ is a group-specific constant fixed over time $\mu_{\text {it }}$ is an idiosyncratic error term

\section{Results}

At the $1 \%$ significance level, the test statistics result for the $\mathrm{F}$ test of the model is found to be significant. The model depicts that the size of the firm significantly affects the total sustainability score, which also had been confirmed in previous literature (Haniffa \& Cooke, 2005; Iyer \& Lulseged, 2013). In line with previous studies by Branco \& Rodrigues (2008) for Portugese companies and Barmmer and Pavelin (2008) for UK firms, the result of this study for TSS depicts that there is no significant relationship between the TSS and ROA. This means that profitability does not influence the attitude of a firm to disclose information on various aspects of sustainability disclosures. The study also confirms that the greater the number of sustainability reports submitted, the greater the value of TSS will be. Consistent with prior literature (Branco \& Rodrigues, 2008; Brammer \& Pavelin, 2008), this study also confirms that the profitability of a firm does not affect the firm's behaviour of reporting on the overall aspects of sustainability. The explicative power of the variables in the total sustainability score is $38.2 \%$, in Indian, $39.8 \%$ in Chinese and $41.9 \%$ in USA context.

Table 1. Summary of Panel OLS regressions analysis, source: Author's calculated values

\begin{tabular}{|l|c|c|c|}
\hline \multirow{2}{*}{ Variables } & Results & \multicolumn{1}{l|}{} \\
\cline { 2 - 4 } & India & China & USA \\
\hline Interc. & $-0.304 * * *$ & $-0.414 * *$ & $-0.461 * *$ \\
\hline ROA & -0.000 & -0.000 & -0.000 \\
\hline Size & $0.021 * * *$ & $0.032 * *$ & $0.029 * * *$ \\
\hline Gearing ratio & -0.000 & -0.000 & -0.000 \\
\hline SR submitted & $0.207 * *$ & $0.311 * * *$ & $0.336 * *$ \\
\hline $\mathrm{R}^{2}$ & 0.382 & 0.398 & 0.419 \\
\hline \multicolumn{4}{|c|}{ Note: $* * * * * p$-value significant at the 5\% and 1\% level }
\end{tabular}

\section{Discussion and Conclusion}

Every society consists of a heterogeneous group of people with unique characteristics and value systems. The stakeholders for a commercial establishment come from this diverse multivariate society and are expected to be ethically driven, especially individuals who hold the offices of the higher echelons to achieve the goal of the organization and the society at large (Zientara, 2015).Corporate behaviour is influenced mostly by the non-financial objectives of society (Gomez-Mejia et al., 2007, Kalam \& GomezMejia, 2016) as observed in the study. The various business operations of a firm bring in emotional and social ties with the employees, suppliers, customers, bureaucrats, industry allies and the society at large, which in turn paves the way for reputational and financial returns. Various economists and social scientists have long tried to find the major reasons for industries that are voluntarily reporting the factual information on socio-economic and ecological aspects. Gond et al. (2012) advocates that an organization will be recorded as ineffective and poor in technological advances if it considers ecological sustainability just as a legal compliance but not as a value by which they are driven, i.e., whenever environmental costs are partially analyzed; then, they are pooled with other types of expenditures like overhead expenses or administrative expenses (Henri et al., 2013).

The present study explores sustainability reporting practices employed by Indian, Chinese, and USA firms that are prone to causing heavy pollution in the last decade i.e., 2007-08 to 2016-17. It gives a detailed account of the evolution in organizational reporting and compliance in the Indian, Chinese, and USA context. The exhaustive literature review carried out for the study led the researchers to focus on four variables, e.g., RoA, size, gearing ratio and separate sustainability report submitted, which are significant for the Indian firms to report on sustainable performance. The study has $\mathrm{R}^{2}$ value ranging from 0.382 to 0.419 , which explains that the above mentioned variables account for ranges only from $38.2 \%$ 
to $40.9 \%$ of the TSS. Loh et al. (2017) in a study conducted in Singapore has obtained similar $\mathrm{R}^{2}$ results. The possible reasons for having the low $\mathrm{R}^{2}$ value in this study could be that the most of firms have just begun to include a separate sustainability report into reporting for regulators to fulfil the compliance. Compliance pressure to disclose socio-economic and ecological performance of the organization is a recent phenomenon, as there was no provision stressing the publishing of SRs by any major acts or laws until recently. It is also noted with great importance that most of the report was qualitative in nature, as no compliance requirements were suggesting that the report should be both qualitative and quantitative.

This study draws inspiration from the legitimacy theory that advocates the need for reporting on sustainability practices for economic prosperity (Fields et al., 2001; Gramerschlag et al., 2010) as well as the wellbeing of the future generations to come. It has also drawn criticism from research like Milne (2002). The present study has utilized the legitimacy theory to examine the existing sustainability reporting practices employed by Indian, Chinese and USA polluting industries. There are four variables taken up for studies, namely, RoA, size of the firms, gearing ratio, and separate sustainability reports published by the firms. The outcome of the study suggests that the size of the firms is directly proportional to the transparency the firm brings in sustainability reporting. The variables RoA and gearing ratio do not have any influence on the total sustainability score, and the publication of a separate sustainability report by the firm does have a positive significant influence on the sustainability score earned by the firms.

The exhaustive literature review by the researchers reveals that the institutional pressure for compliance does not improve the sustainability performance of the organizations, especially in India, as there are few resources when compared to Chinese, and USA economies. The present study adds to the existing body of knowledge that developed economies such as the USA, emerging economies such as India and China have also begun to work towards compliance standards to ensure that sufficient resources are available for future generations. This research work also suggests concrete implementable solutions to strengthen the existing form of reporting to bring in greater transparency and thus empower all the stakeholders involved. The researchers do agree that sustainability reporting has seen considerable advancement in the time-period taken for study.

The present study contributes to the existing literature on sustainability practices and its reporting. First, unlike the previous studies in the Indian, Chinese, and USA context, this study is based on a larger dataset with both time series and cross-sectional data. It provides empirical evidence of the relationship that exists between the total sustainability score and its various sub-categories with due consideration to the size of the firms. The study also draws attention towards the possible reasons for organizational ineffectiveness in adopting sustainability accounting practices. This study will also help policymakers and regulators gain a bird's eye view on various aspects of sustainability reporting practiced by various firms for providing clean and healthy business environments. These firms can set standards for all firms in the area of sustainable development.

\section{Annexure}

List of industry and number of sample firms, source: $\mathrm{Au}-$ thor's calculate values

\begin{tabular}{|l|l|c|c|c|}
\hline $\begin{array}{l}\text { S1 } \\
\text { No }\end{array}$ & Industry & $\begin{array}{l}\text { No. of } \\
\text { Indian } \\
\text { Firms }\end{array}$ & $\begin{array}{l}\text { No. of } \\
\text { Chi- } \\
\text { nese } \\
\text { Firms }\end{array}$ & $\begin{array}{l}\text { No. of } \\
\text { US } \\
\text { Firms }\end{array}$ \\
\hline 1 & $\begin{array}{l}\text { Mining, oil, and } \\
\text { metal extraction }\end{array}$ & 100 & 100 & 100 \\
\hline 2 & Chemical & 100 & 100 & 100 \\
\hline 3 & Pharmaceutical & 100 & 100 & 100 \\
\hline 4 & $\begin{array}{l}\text { Fertilizer and } \\
\text { agrochemical }\end{array}$ & 36 & 50 & 50 \\
\hline 5 & Cement & 44 & 50 & 50 \\
\hline \multicolumn{2}{|l|}{ Total } & 380 & 400 & 400 \\
\hline
\end{tabular}

\section{References}

1. ADAMS C., NARAYANAN V., 2007, The standardization of sustainability reporting, in: Sustainability Accounting and Accountability, ed. Unerman J., Bebbington J., O'Dwyer B., Routledge, London and New York, p. 70-85.

2. AKISIK O., GAL G., 2014, Financial performance and reviews of corporate social responsibility reports, in: Journal of Management Control, 25(3-4), p. 259288.

3. AUPPERLE G., CARROL A., HATFIELD J., 1985, An empirical examination of the relationship between corporate social responsibility and profitability, in: Academy of Management Journal, 22, p. 501-515.

4. BANSAL P., HOFFMAN A. J., 2012, The Oxford handbook of business and the natural environment, Oxford University Press, Oxford.

5. BEBBINGTON J., LARRINAGA C., 2014, Accounting and sustainable development: An exploration, in: Accounting, Organizations and Society, 39(6), p. 395-413.

6. BEBBINGTON J., LARRINAGA C., MONEVA J. M., 2008, Corporate social reporting and reputation risk management, in: Accounting, Auditing and Accountability Journal, 21(3), p. 337-361.

7. BEBBINGTON J., UNERMAN J., O'DWYER, B., 2014, Sustainability accounting and accountability, Routledge, Abingdon.

8. BEWLEY K., LI Y., 2000, Disclosure of environmental information by Canadian manufacturing companies: a voluntary disclosure perspective, in: $A d$ vances in Environmental Accounting \& Management, 1, p. 201-226.

9. BRAMMER S., PAVELIN S., 2008, Factors influencing the quality of corporate environmental disclosure, in: Business Strategy and the Environment, 17, p. 120-136. 
10. BRANCO M., RODRIGUES L., 2008, Factors influencing social responsibility disclosure by Portuguese companies, in: Journal of Business Ethics, 83, p. 68$-701$

11. BURRITT R. J., TINGEY-HOLIOYAK J., 2012, Forging cleaner production: the importance of academic-practitioner links for successful sustainability embedded carbon accounting, in: Journal of Cleaner Production, 36 (1) , p. 39-47.

12. CAMPBELL J. L., 2007, Why would corporations behave in socially responsible ways? An institutional theory of corporate social responsibility, in: Academy of Management Review, 32(3), p. 946-967.

13. CHEN J. C., ROBERTS R. W., 2010, Towards a more integrated understanding of the organizationsociety relationship: Implications for social and environmental accounting research, in: Journal of Business Ethics, 97(4), p. 651-665.

14. CHEN S., BOUVAIN P., 2009, Is corporate responsibility converging? A comparison of corporate responsibility reporting in the USA, UK, Australia, and Germany, in: Journal of Business Ethics, 87, p. 299317.

15. CLARKSON P. M., LI Y., RICHARDSON G. D., VASVARI F. P., 2008, Revisiting the relation between environmental performance and environmental disclosure: An empirical analysis, in: Accounting, Organizations and Society, 33(5), p. 303-327.

16. COLI M., NISSI E., RAPPOSELLI A., 2011, Monitoring environmental efficiency: an application to Italian provinces, in: Environmental Modelling \& Software, 26(1), p. 38-43.

17. DEEGAN C., BLOMQUIST C., 2006, Stakeholder influence on corporate reporting: An exploration of the interaction between WWF-Australia and the Australian minerals industry, in: Accounting, Organizations and Society, 31(4-5), p. 343-372.

18. DYLLICK T, HOCKERTS K., 2002, Beyond the Business Case for Corporate Sustainability, in: Business Strategy and the Environment, 11, p. 130-141.

19. ECCLES R., IOANNOU I., SERAFEIM G., 2012, The impact of corporate sustainability on organizational processes and performance, in: Working paper, Harvard Business School, Harvard University, Boston.

20. ELKINGTON J., 2002, The Triple Bottom Line of the 21st Century, Oxford Press, Oxford.

21. FIELDS T.D., LYS T.Z., VINCENT L, 2001, Empirical research on accounting choice, in: Journal of Accounting and Economics, 31, p. 255-307.

22. FRIEDMAN, M. (2007). The social responsibility of business is to increase its profits, in: Corporate social responsibility. Volume 1: theories and concepts of corporate social responsibility, eds. Crane A, Matten D, Sage Publications, London, p. 69-74.

23. FROOMAN J., 1999, Stakeholder influence strategies, in: The Academy of Management Review, 24(2), p. 191-205.

24. GAMERSCHLAG R., MÖLLER K., VERBEETEN F., 2011, Determinants of voluntary CSR disclosure: empirical evidence from Germany, in: Review of Managerial Science, 5 (23), p. 233-262.

25. GAVANA G., GOTTARDO P., MOISELLO A.M., 2017, Sustainability Reporting in Family Firms: A Panel Data Analysis, in: Sustainability, 9, p. 38.

26. GODHA A., JAIN P., 2015, Sustainability reporting trend in Indian companies as per GRI framework: a comparative study, in: South Asian Journal of Business and Management Cases, 4(1), p. 62-73.

27. GOMEZ-MEJIA L.R., HAYNES K.T., NUNEZNICKEL M., JACOBSON K.J.L., MOYANOFUENTES J., 2007, Socioemotional wealth and business risks in family-controlled firms: Evidence from Spanish olive oil mills, in: Administrative Science Quarterly, 52, p. 106-137.

28. GOND J.P., GRUBNIC S., HERZING C., MOON J., 2012, Configuring management control systems: theorizing the integration of strategy and sustainability, in: Management Accounting Research, 23(3), p. 205-223.

29. GRAY R., 2010, Is accounting for sustainability actually accounting for sustainability and how would we know? An exploration of narratives of organizations and the planet, in: Accounting, Organizations and Society, 35(1), p. 47-62.

30. GRAY R., KOUHY R., LAVERS S., 1995, Corporate social and environmental reporting: A review of the literature and a longitudinal study of UK disclosure, in: Accounting, Auditing \& Accountability Journal, 8(2), p. 47-71.

31. GRI, 2013, https://www.globalreporting.org/information/news-and-press-center/Pages/GRI-amongthe-most-popular-CSR-instruments.aspx (13.09.2017).

32. GRI, 2009, https://www.globalreporting.org/resource library/GRI-Sustainability-Report-2009-2010.pdf (30.09.2017).

33. HANIFFA R.M., COOKE T.E., 2005, The impact of culture and governance on corporate social reporting, in: Journal of Accounting and Public Policy, 24, p. 391-430.

34. HENRI J., BOIRAL O., ROY M.J., 2013, The tracking of environmental costs: motivations and impacts, in: European Accounting Review , DOI: $10.1080 / 09638180.2013 .837400$.

35. HUSTED B.W., SALZAR J., 2006, Taking Friedman seriously: maximizing profits and social performance, in: Journal of Management Studies, 43(1), p. 75-91.

36. IPPC (INTERGOVERNMENTAL PANEL ON CLIMATE CHANGE), 2014, IPCC fifth assessment synthesis report, https://www.ipcc.ch, (13.09.2017)

37. ISLAM M. A., DEEGAN C., 2010, Media pressures and corporate disclosure of social responsibility performance: a case study of two Global clothing and sports retail companies, in: Accounting and Business Research, 40(2), p. 131-148.

38. IYER V., LULSEGED A., 2013, Does family status impact US firms' sustainability reporting?, in: Sustainability Accounting, Management and Policy Journal, 4, p. 163-189.

39. JACKSON T., 2009, Prosperity without growth, Earthscan, London.

40. KALM M., GOMEZ-MEJIA L.R., 2016, Socioemotional wealth preservation in family firms, in: Revista de Administração, 51, p. 409-411.

41. KAUR A., SHARMA P.C., 2017, Environment Development Sustainability, DOI: $10.1007 / \mathrm{s} 10668-017-9961-5$.

42. KOLK A., 2005, Environmental reporting by multinationals from the Triad: convergence or divergence, in: Management International Review, 45(1), p. 145166. 
43. KUMAR A., DAS N., 2018, Sustainability Reporting Practices in Emerging Economies: A Cross-Country Study of BRICS Nations, in: Problemy Ekorozwoju/ Problems of Sustainable Development, 13(2), p. 1725.

44. KOTHARI A., 2013, Development and ecological sustainability in India: Possibilities for Post-2015 framework, in: Oxfam India working paper series, http://www.environmentportal.in/files/file/development $\% 20$ and $\% 20$ ecological $\% 20$ sustainability $\% 20$ in\%20india.pdf (15.05.2016).

45. KUOSMANEN T., KUOSMANEN N., 2009, How not to measure sustainable value (and how one might), in: Ecological Economics, 69(2), p. 235-243.

46. LAINE M., 2010, Towards sustaining status quo: Business talk of sustainability in Finnish corporate disclosures 1987-2005, in: European Accounting Review, 19(2), p. 247-274.

47. LINDBLOM C. K., 1993, The implications of organizational legitimacy for corporate social performance and disclosure, in: The critical perspectives on accounting conference, New York.

48. LOH L., THOMAS T., WANG Y., 2017, Sustainability Reporting and Firm Value: Evidence from Singapore-Listed Companies, in: Sustainability, DOI:10.3390/su9112112.

49. MALSCH B., 2013, Politicizing the expertise of the accounting industry in the realm of corporate social responsibility, in: Accounting, Organizations and Society, 38(2), p. 149-168.

50. MANI V., GUNASEKARAN A., PAPADOPOULOS T., HAZEN B., DUBEY R., 2016, Supply chain social sustainability for developing nations: Evidence from India, in: Resources Conservation and Recycling, 111, p. 42-52.

51. MCWILLIAMS A., SIEGEL D., 2001, Corporate social responsibility: a theory of the firm perspective, in: The Academy of Management Review, 26(1), p. 117-127.

52. MEBRATU D., 1998, Sustainability and Sustainable Development: Historical and Conceptual Review, in: Environmental Impact Assessment Review, 18, p. 493-520.

53. MILNE M. J., 2002, Positive accounting theory, political costs and social disclosure analyses: a critical look, in: Critical Perspect Account, 13, p. 369395.

54. MILNE M. J., GRAY R., 2013, W(h)ither ecology? The triple bottom line, the Global Reporting Initiative and corporate sustainability reporting, in: Journal of Business Ethics, 118(1), p. 13-29.

55. MILNE M., TREGIDGA H., WALTON S., 2009, Words not actions! The ideological role of sustainable development reporting, in: Accounting, Auditing \& Accountability Journal, 22(8), p. 1211-1257.

56. MUNDA G., SAISANA M., 2011, Methodological considerations on regional sustainability assessment based on multicriteria and sensitivity analysis, in: $R e$ gional Studies, 45(2), p. 261-276.

57. OWEN D. L., 2008, Chronicles of wasted time? A personal reflection on the current state of, and future prospects for, social and environmental accounting research, in: Accounting, Auditing \& Accountability Journal, 21(2), p: 240-267.
58. PARKER L. D., 2005, Social and environmental accountability research: A view from the commentary box, in: Accounting, Auditing \& Accountability Journal, 18(6), p. 842-860.

59. PARRIS T. M., KATES R. W., 2003, Characterizing and measuring sustainable development, in: Annual Review of environment and resources, 28(1), p. 559586.

60. PERES-NETO P. R., LEGENDRE P., DRAY S., BORCARD, D., 2006, Variation partitioning of species data matrices: estimation and comparison of fractions, in: Ecology, 87(10), p. 2614-2625.

61. ROCKSTRÖM J., STEFFEN W., NOONE K., PERSSON Å., CHAPIN III F.S., LAMBIN E.F., LENTON T.M., SCHEFFER M., FOLKE C., SCHELLNHUBER H.J., NYKVIST B., 2009, A safe operating space for humanity, in: Nature, 461(7263), p. 472.

62. RODRIGUE M., MAGNAN M., \& CHO C. H., 2013, Is environmental governance substantive or symbolic? An empirical examination, in: Journal of Business Ethics, 114(1), p. 107-129.

63. SODHI M.S., 2015, Conceptualizing social responsibility in operations via stakeholder resource-based view, in: Production and Operations Management, 24(9), p. 1375-1389.

64. SPAR D., LAMURE L., 2003, The power of activism: Assessing the impact of NGOs on global business, in: California Management Review, 45(3), p. 78-101.

65. SPENCE C., 2009, Social accounting's emancipatory potential, in: Critical Perspectives on Accounting, 20(2), p. 205-227.

66. SUCHMAN M. C., 1995, Managing legitimacy: Strategic and institutional approaches, in: Academy of Management Review, 20(3), p. 571-610.

67. TANG C. S., ZHOU S., 2012, Research advances in environmentally and socially sustainable operations, in: European Journal of Operational Research, 223(3), p. 585-594.

68. TREGIDGA H., MILNE M., KEARINS K., 2014, (Re)presenting 'sustainable organizations', in: Accounting, Organizations and Society, 39(6), p. 477494.

69. TYTECA D.,1998, Sustainability indicators at the firm level, in: Journal of Industrial Ecology, 2(4), p. 61-77.

70. WATTS R.L., ZIMMERMANN J.L., 1990, Positive accounting theory: a ten year perspective, in: Account Review, 65(1), p. 131-156.

71. WINFIELD M., GIBSON R. B., MARKVART T., GAUDREAU K., TAYLOR J., 2010, Implications of sustainability assessment for electricity system design: The case of the Ontario Power Authority's integrated power system plan, in: Energy Policy, 38(8), p. 4115-4126.

72. ZIENTARA P., 2015 Socioemotional wealth and corporate social responsibility: A critical analysis, in: Journal of Business Ethics, 144(1), p. 185-199.

73. ZHOU H., YANG Y., CHEN Y., ZHU J., 2017, Data Envelopment Analysis Application in Sustainability: The Origins, Development and Future Directions, in: European Journal of Operational Research, 264(1), p. 1-16. 